\title{
Kwementyaye Perrurle Perkins: a personal memoir
}

This memoir recounts my personal association with Kwementyaye (Kumantjay), better known to most outside his family as Charles Perkins, from the 1930s to 2000. Before he was made human through initiation ceremonies in the Arrernte way, Charles and I were both born in the Native Institution, the Bungalow Telegraph Station, in Alice Springs, where his ashes were scattered. In 1942 our paths diverted: he went to live in Alice Springs, where his mother Hettie Perkins (Senior) worked for the military and I was evacuated away from the expected Japanese invasion to a wartime refugee camp at Mulgoa, New South Wales.

While working in military kitchens, Hettie and her younger children lived in overcrowded accommodation; Charlie was left to the devices of his young peers who came under the notice of the townsfolk and the military and civil police. The Reverend Percy McDonald Smith took Charlie under his care first at St John's and then the St Francis Anglican home for boys of mixed Aboriginal and other descent in Semaphore South, Adelaide.

Meanwhile, I stayed at Mulgoa while my mother Eileen went to work in Sydney under the wartime Aboriginal employment program. She worked as a cook and occasionally we spent time together. While in Sydney my mother had another child and with them I set off to return to Alice Springs. En route we were prevented from returning due to the martial law in force. The military authorities placed us in an aliens' camp at Balaclava in South Australia until the Pacific War ended. My mother was given the opportunity to place me under the care of Rev. Smith. They both knew that there were no proper schools in Alice Springs for half-castes and my mother took up the offer of schooling in Adelaide. Like Hettie Perkins, my mother consented to leave me at the St Francis boys' home. So Charlie Perkins, who was just two years older, and I together became inmates at the St Francis home.

Charlie was outstanding in singing and this is one of my earliest memories of him, although he never made much of an impression upon me until the numbers at St Francis grew in 1950. The Commonwealth government introduced endowment and extended this to parents of half-castes. We in St Francis drew Commonwealth support because of that and also because we were Northern Territory wards being educated outside the Northern Territory. These payments also enabled us to play sport and some of us began to attend high school, whereas before that the Australian Board of Missions had to pay. At St Francis the Anglican Church leased land to a local soccer team, Port Thistle. Charlie played for the senior colts and I played for the junior team. We became much closer. I always cleaned Charlie's football boots after milking the cows on Saturday mornings. He gave me a small payment in kind and I tracked him to watch his games. He soon gravitated into the first team. He quickly became a soccer star and was 
in demand among many of the ethnic teams such as International, a mixed ethnic team, and Budapest, the Hungarian team. I left for work in the country and Charlie went overseas to play for Bishop Auckland near Newcastle in England.

We teamed up again in 1967 when I came back to Adelaide to play Australian Rules and Charlie had returned from England. I switched to soccer and signed for the Croatia club, where Charlie was captain-coach. Together we played in the first team. Charlie was selected in the South Australia team with John Moriarty, another former St Francis boy who played with Juventus, and the three of us were inseparable. We shared our social gatherings and travels to the country, and I was with Charlie on the night he met his future wife, Eileen, at the Hendon pub.

Charlie worked for the South Australian Railways and enjoyed the power that came from trade union membership. He talked of his impression of learning how to deal with Railways bosses, arguing for employment conditions for his workmates. At the very same time we were involved with the Aboriginal Progress Association with other Aborigines and South Australians with Labor Party connections. There were Malcolm and Aileen Cooper, Vince Copley, John Moriarty, Maude and George Tongery, Geoff and Nancy Barnes, Charlie and myself. We sought emancipation from South Australia's race legislation. We held meetings with Don Dunstan (later the Premier) and Cameron (later Justice) Stewart. These meetings focused on, first, a repeal of exemptions under the Aboriginal legislation and, second, Aboriginal human rights. Then Charlie entered national politics too.

In 1958 he had drawn the criticism of Dr Charles Duguid, the Presbyterian missionary of Ernabella and an Adelaide ear, nose and throat specialist. Duguid had created the Aborigines Advancement League in South Australia and had helped establish the Colebrook Girls Home for girls of mixed Aboriginal descent from the northern area of South Australia. Duguid's criticism focused on Charlie's election in Brisbane to a national body called the Federal Council for the Advancement of Aborigines. Duguid believed he was more qualified than Charlie, who found a sense of power in belonging to this body and wouldn't allow himself to be diverted by Duguid's views. Soon I left for England and soccer and he left for Sydney to get married, take up matriculation studies and emerge as the most profound Aboriginal social and civil rights thinker of his era.

When 1 returned from England Charlie was studying Arts at Sydney University and playing football for Bankstown. He went on to conduct the freedom ride and become the first Aboriginal university graduate. His achievements influenced me, encouraging me to follow in his academic footsteps. He, however, achieved much more. He played an important role in securing a 'Yes' vote at the 1967 referendum on the Commonwealth's powers in Aboriginal affairs; he created the Foundation for Aboriginal Affairs in Sydney; and then he joined the Commonwealth Public Service, but not before conducting a world tour to study race questions overseas. While away he met important British and American Black leaders and maintained his contacts with them.

Charlie led the fight to change white society. He conflicted notoriously with goverrment ministers, and was so determined he was not afraid to defy them. It was that which caused his downfall. Under the Hawke government he humiliated the Minister for Aboriginal Affairs, Jerry Hand, by encouraging Aborigines to revolt in 1988. As 
Prime Minister, Hawke was forced to side with Perkins. This began a conspiracy among Aboriginal bureaucrats. Charlie never forgave those involved and he retreated inwardly before returning to central Australia, where he went through traditional initiation ceremonies. He created the Arrernte Council and ran successfully for further public office, this time as a member of the new Aboriginal and Torres Strait Islander Commission. He had earlier written an autobiography, $A$ bastard like me, but in 1990 was also the biographical subject of serious scholarship in Dr Peter Read's Charles Perkins: a biography. Charlie received an honorary doctorate from the University of Western Sydney in 1999 and many of his publications were his public speeches on Aboriginal affairs. Thousands of Australians mourned his passing, but mostly Aborigines will mourn and remember him.

Dr Gordon Briscoe

Historical Studies

Research School of Social Sciences

Australian National University 